doi: $\underline{10.31211 / \text { interacoes.n34.2018.a4 }}$

\title{
The Three Levels of the Digital Divide: Barriers in Access, Use and Utility of Internet among Young People in Spain
}

\author{
Daniel Calderón Gómez \\ Universidad Complutense de Madrid - danielcalderon@ucm.com
}

\begin{abstract}
This paper explores the three levels of digital divide among young people living in the region of Madrid (Spain). We use a qualitative approach, based on 20 in-depth interviews, in order to describe the personal process of Internet appropriation among this collective, taking into account the differences associated to gender, age, education, geographical habitat and type of technology use. Taking into account the three levels of the digital divide, we explore

5 important barriers (access, skills, motivation, emotions and utility) that influence the type of use of digital technologies by young people. We conclude that, even among youngsters who frequently use digital technologies, there are important asymmetries and barriers that limit the utility they can get from them, related to their sociocultural background and their personal processes of technological socialization.
\end{abstract}

Keywords: Youth, digital technologies, Internet, digital divide

\section{Os Três Níveis da Divisão Digital: Barreiras no Acesso, na Utilização e na Utilidade da Internet Entre Jovens em Espanha}

\section{Sumário}

Este artigo explora os três níveis de exclusão digital entre os jovens que vivem na região de Madrid (Espanha). Utilizamos uma abordagem qualitativa, baseada em 20 entrevistas em profundidade, para descrever o processo pessoal de apropriação da Internet neste coletivo, levando em consideração as diferenças associadas ao género, idade, escolaridade, geografia do habitat e tipo de uso da tecnologia. Levando em conta os três níveis da clivagem digital, exploramos 5 bar- reiras importantes (acesso, competências, motivação, emoções e utilidade) que influenciam o tipo de utilização das tecnologias digitais por parte dos jovens. Concluímos que, mesmo entre os jovens que utilizam frequentemente as tecnologias digitais, existem importantes assimetrias e barreiras que limitam a utilidade que delas podem obter, relacionadas com o seu background sociocultural e os seus processos pessoais de socialização tecnológica.

Palavras-chave: Juventude, tecnologias digitais, Internet, clivagem digital 


\section{INTRODUCTION. YOUTH AND DIGITAL TECHNOLOGIES}

The process of digitalization (Croon Fors, 2013) and the rising of the information society (Feather, 2013) have supposed a large transformation of both modes of production and organization of capitalist societies and people's daily practices. In this sense some authors have announced the advent of a third industrial revolution (Castells, 2011; Rifkin, 2011), that would be based on the global production and distribution of information. Although the process of computerisation started almost 30 years before, it was specifically during the 1990s when personal computers and Internet connections started to arrive massively to the domestic realm, and ordinary people began to use these technologies in their daily activities, as Bakardjieva (2005, p. 4) has pointed out.

In the youth studies literature, since the start of this digitalization process it was common to highlight the affinity of new generations with digital technologies, speculating about the transformative potential of these technologies in relation to learning processes, communication practices or leisure activities. Concepts such as technology generation (Weymann \& Sackmann, 1994), Net generation (Tapscott, 1998), digital generation (Buckingham, 2006), millennial generation (Howe \& Strauss, 2000) or the famous dichotomy between digital natives and digital immigrants (Prensky, 2011) populated the academic literature and the mass media, trying to define new generations by means of their embracing of technological patterns. Although most of these typologies have been questioned because of their determinist approach to technological diffusion (Kretchmer, 2018; Ragnedda, 2017; Zimic \& Dalin, 2011), the the essentialization of youth (Buckingham, 2011) and their outrageous lack of empirical evidence (Jones \& Shao, 2011; Selwyn, 2009), they are still very popular tools to make sense of young people's digital practices. This form of generational marketing (Haddon, 2007) has been fed up by the development of digital culture industries, which focused on children, teenagers and youngsters as their main marketing targets (Montgomery, 2009).

The association of youth with technological change is not precisely new; for instance, in the American post-war context it was common to highlight the affinity between youngsters' and TV media culture (Buckingham, 2002). However, what is characteristic of this digital natives' rhetoric is the cyber-utopian approach that underlines the potential transformative logics of technology adoption and diffusion. Since they are the first generation socialized through digital technologies, young peo- 


\section{The Three Levels of the Digital Divide: Barriers in Access,}

\section{Use and Utility of Internet among Young People in Spain}

ple are conceptualized as the true native inhabitants of the digital world, proficient in the use of new technological innovations and able to speak the language of digital platforms, whereas the older generations are digital immigrants, who always retain their pre-digital accent, their foot in the past (Prensky, 2001). Because of their intuitive and innate affinity towards digital spheres, young people seems to have better digital skills than their parents, being much better prepared to confront the challenges of the information society and to build the digital society of the future, which would seemingly be characterized by a more flexible and entrepreneurial approach to labour, a more democratic decision making (Tapscott, 2008) and a new scale of values, associated with civic engagement and prosocial attitudes (Howe \& Strauss, 2000).

This utopic model of technological transformation, and its association to young people, has been extremely controversial among academia, because it presents the stereotypical ideal of young hyper-connected people, intuitively tech-savvy and prone to accept flexibility and instability in their labour career because of their entrepreneurial attitude towards work. As Selwyn has pointed out, "the notion of the 'digital native' should be seen more as a discursive than descriptive device, employed by those seeking to exert some form of power and control over the shaping of the digital (near)future" (2009, p. 371). In other words, there is an ideological affinity between this reductionist approach to young people, which invisibilize diversity and inequality, and the neoliberal capitalist basis of the information society which promotes digitalization, as some critical authors stress (Banaji, 2011; Gilleard, 2018; Jones, 2011). In order to counter this utopian narrative of progress, digital divide approaches have studied the diverse ways in which digital technologies and the information society are reproducing and enhancing social stratification.

\section{THE THREE LEVELS OF THE DIGITAL DIVIDE}

Digital divide studies have shown how the advent of the information society was engendering new processes of social stratification. As new media and technologies became more important in the articulation of economic, social, and cultural dynamics, new forms of dependency on digital technologies emerged, and exclusion from the digital society also became a new form of social exclusion (Antonio \& Tuffley, 2014; Beauchamps, 2012; Sparks, 2013; Van Aerschot \& Rodousakis, 2008). The ar- 
rival of information society is an ambivalent process (Castells, 2011), as it potentially promotes new forms of liberation but also engenders new forms of domination and social exclusion (Espín, 2011; Mariën \& Prodnik, 2014). Digital divide studies, consequently, have progressively changed our understanding of the issue and have focused on different aspects of digital inequality, following the pace of technological and social transformations that experienced contemporary society from the mid-90s to the present.

The first digital divide studies, during the 90s, focused on the access to digital technologies and to the Internet (Ghobadi \& Ghobadi, 2015). Firstly, they described the different degree of Internet penetration among developed and developing countries, but, progressively, started to highlight asymmetries among regions, collectives and social groups in developed countries (Compaine, 2001). It was clear that the pace of digitalization was not equally distributed among the entire population (Norris, 2000), and thus the main issue was how to foster policies to promote the Internet access among vulnerable groups, who did not have the economic resources to pay for expensive devices and domestic Internet connections. This political approach to digital inclusion, which was later called the 'first level of digital divide' or 'access gap' (Van Deursen \& Van Dijk, 2015) was still extremely naïve because, as Ragnedda has pointed out, it "mainly focuses on the cost and diffusion of technologies, reducing the phenomenon of the digital divide to a technological and economic issue" (2017, p. 16). More importantly, this approach was based on a deterministic vision that hid the social aspects of digital inequality, as it sustains that the mere promotion of people's access to digital technologies can actually reduce inequality (Ragnedda, 2017, p. 20). The problem lies on a binary conceptualization of access, the model of 'have and have nots' (Haight, Quan-Haase, \& Corbett, 2014; Selwyn, 2004; Van Deursen \& Van Dijk, 2013), in which digital connectivity is reduced to having access, or not, to the Internet.

Recent studies have tried to develop a more complex understanding of the first digital divide, investigating the link between conditions of access and digital inequalities: for instance, Gonzales have developed the technological maintenance theory (2016), that focuses on the economic impact of the cost of the Internet connection and of keeping the computer updated. Other authors have focused on the consequences of using different devices to access to the Internet, comparing smartphone and computer oriented activities (Pearce \& Rice, 2013) or highlighting the importance of multiple access (Van Deursen \& Van Dijk, 2015, p. 380). That is, the access 
The Three Levels of the Digital Divide: Barriers in Access, Use and Utility of Internet among Young People in Spain

though different devices makes possible to benefit from the wide array of possibilities offered by new technologies. Finally, some temporal, social, cultural and economic constrains also influence the quality of young people's access, and that enables some digital practices and inhibits others (Robinson, 2009, 2013). In figure 1 we summarize the main aspects of the access gap.

Figure 1. Evolution of First Digital Divide Studies

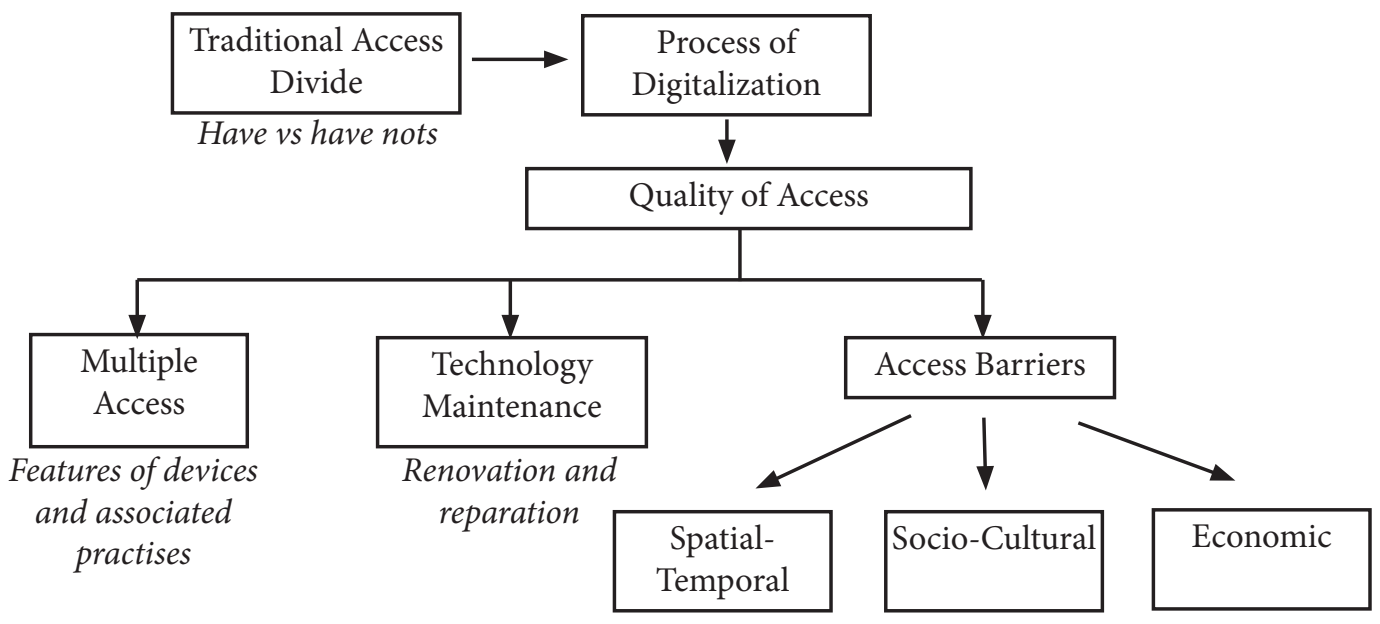

Source: Own elaboration

The process of digitalization made evident in the mid-2000s that access to the Internet was not anymore the central issue of digital stratification among young people in developed countries, except for the most vulnerable social groups. This fact motivated the apparition of the 'second level of digital divide' (Castaño, 2008; Correa, 2016) or 'usage gap' (Van Deursen \& Van Dijk, 2013). Here the focus moves, beyond access, to the different ways in which digital technologies are used, taking into account people's social, cultural and economic backgrounds, as well as their motivations, interests and digital skills. Empirical research about the usage gap in young people contributed to question the idea that youngsters form a homogeneous collective in terms of Internet use; as Internet access is quite generalized among youth, it would be more correct to think about several digital generations (Buckingham, 2006), and not just one idealised group of cyber-savvy users. Several typologies of young users have been developed (Dutton \& Blank, 2015; Dutton \& Reisdorf, 2017; Gire \& Gran- 
jon, 2012; Robinson, 2014) that tries to make sense of these various sorts of Internet domestication (Haddon, 2007) among young people. Especially relevant for us is the distinction between visitors and residents (White \& Le Cornu, 2011), very akin to the one elaborated by Laura Robinson between task-oriented and leisure-oriented informational habitus (2009). This author analyses the relation between quality of access, attitudes towards technology and effective use of digital technologies, and shows how youngsters with a better quality of access to the Internet experience an informational advantage (Robinson, 2012) in contraposition with their low-quality access counterparts, who can only use digital technologies for specific tasks and deal with important temporal, spatial and economic constraints.

Beyond these users classifications, second digital divide studies have contributed to build a more nuanced and multidimensional conceptualization of digital inequality (Ghobadi \& Ghobadi, 2015; Mariën \& Prodnik, 2014; Ragnedda, 2017) and to evidence new gaps or barriers that influence Internet appropriation by subjects. In this paper, we are going to focus in three relevant gaps-apart from material access-that also influence young people use of digital technologies. The first one is the 'skills gap' (DiMaggio \& Hargittai, 2001) which is related to the different competencies that are needed to make use and take advantage of digital technologies. Once it was obvious that youngsters were not the skilled digital generation promised by cyber-utopic approaches, the promotion of digital literacy among new generations became a central issue of the political digital agenda (Livingstone, 2008). Van Dijk and van Deursen (2014), for instance, distinguish between 'medium-oriented skills', the technic and operational capacities needed to physically operate digital equipment, and 'contentoriented skills', the ability of benefit from the potentialities of digital technologies, that include communicational skills, information-seeking skills, content creation skills and strategic skills.

The second barrier is the 'motivation gap', which has been described in the 4 gap model (Van Deursen \& Van Dijk, 2015), where the process of digital inclusion (or exclusion) is analysed by means of a complex interaction between motivation, access, skills and use of the Internet. The motivational dimension of Internet domestication has been highlighted recently in empirical works (Dutton \& Blank, 2015; Dutton \& Reisdorf, 2017; Van Aerschot \& Rodousakis, 2008) and shows how people's attitudes towards technologies, particular interests in specific features of ICT (such as communication, videogames and leisure, information retrieval, etc.) or motivation, in general terms, play an important role in young people appropriation of technolo- 


\section{The Three Levels of the Digital Divide: Barriers in Access, Use and Utility of Internet among Young People in Spain}

gies, especially regarding the process of skill acquisition, which is mainly produced gradually through the incorporation of these technologies to daily practices. It is also important to consider the process of self-exclusion of the digital world because, as Gonzales points out, "the idea that some individuals choose not to be online has been labelled a form of motivational access, determined by a combination of cultural and psychological factors" (2016, p. 5).

The third barrier is related to the 'emotional gap', that is, the emotions involved in people's daily use of digital technologies. According to the studies that highlight the emotional costs of digital activity (Huang, Robinson, \& Cotten, 2015; Klinkisch \& Suphan, 2018; Robinson, 2009), there is a strong affective component in Internet use. When people deal with material, social or cognitive constraints that limit their access to digital technologies, such as lack of time, low-quality equipment or lack of self-perceived skills, they are predisposed to feel negative emotions such as anxiety, pressure or frustration. This kind of emotions can act as barriers for Internet use, blocking the process of digital domestication and, at the end, engendering processes of self-exclusion.

Notwithstanding its undeniable contribution to diversify digital inequality empirical studies, the second digital divide perspective has an important limitation that is related to the fact that "the development of the theoretical aspect of digital divide studies has lagged behind the development of more empirical studies" (Ragnedda \& Muschert, 2018a, p. 2). Therefore, many studies have analysed different forms of digital inequality (typologies of use, digital skills, motivations, etc.), but there is little reflection about the articulation of digital inequalities with more general sociological theories about social inequalities. There is an exception in Bourdieu's theory of capitals, which has been extensively used in digital divide approaches (Ragnedda \& Ruiu, 2018; Robinson, 2009; Straubhaar, Tufekci, Spence, \& Rojas, 2012). Also, the recent book Theorizing Digital Divides (Ragnedda \& Muschert, 2018b) presents some other social theories appropriate to analyze digital inequality, such as Simmel's theory of information (Muschert \& Gunderson, 2018), de-colonial theory (Moyo, 2018) or social constructionism (Kretchmer, 2018), among others. Based on a Weberian approach to stratification, Ragnedda has also recently developed the concept of the 'third level of the digital divide' (2017), which is referred to the offline outcomes and benefits that people get by using digital technologies, emerging a new gap, that we could call 'utility gap'. This perspective avoids the false dichotomy between online and offline dimensions of reality, and tries to ground digital inequalities in digital practices in 
people's social activities and life trajectories. Under this perspective, we can close the circle of digital and social stratification (figure 2) and understand how digital inequalities are not only reproducing but also deepening previous processes of social stratification:

"I shall argue that there exists a kind of recurring cycle between social and digital inequalities. That is, social inequalities are the root of digital inequalities, and at the same time digital inequalities increase and reinforce social inequalities already present in a stratified social sphere" (Ragnedda, 2017, p. 48).

Figure 2. Three levels of digital divide. Circle of social-digital inequality

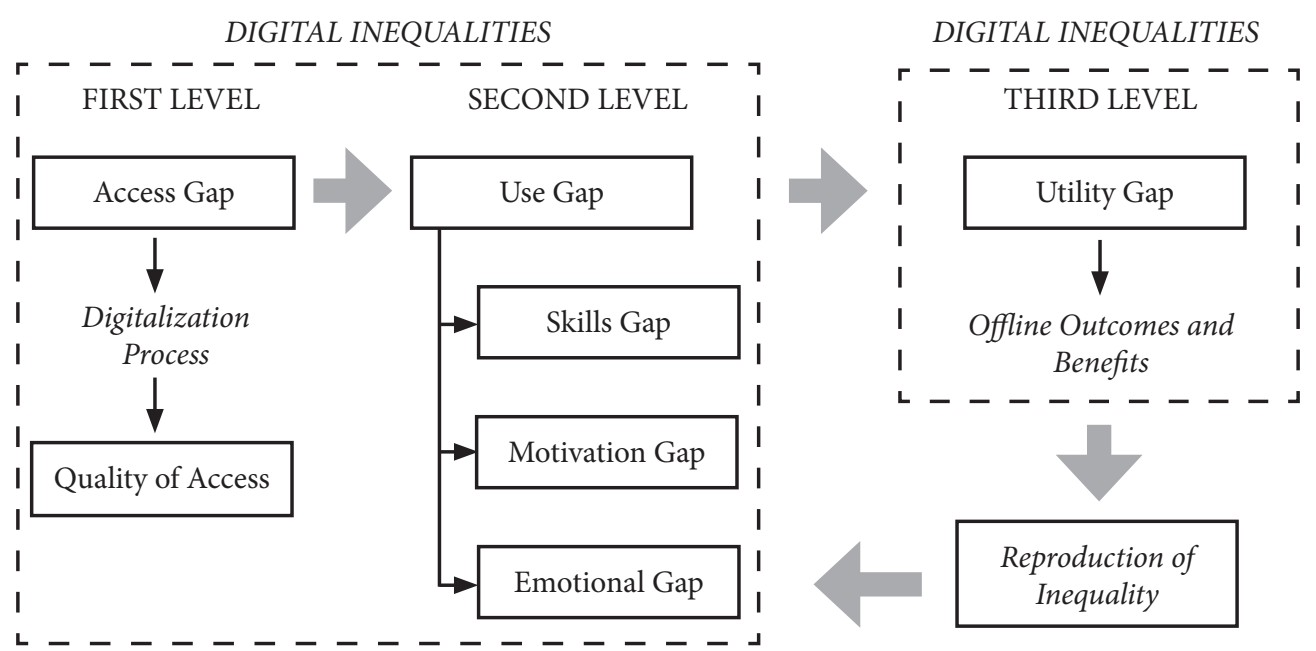

Source: Own elaboration based on Ragnedda (2017, p. 51)

\section{METHODOLOGY}

The methodology of this paper is qualitative, based on 20 in-depth interviews, which serve to analyse the biographical processes of technological socialization among young people living in the region of Madrid, Spain. Specifically, in this paper we focus on those youngsters whose basic access to digital technologies is already granted. Accordingly, our main research question concerns the identification of the 


\section{The Three Levels of the Digital Divide: Barriers in Access, Use and Utility of Internet among Young People in Spain}

main gaps related to access, skills, motivation, emotions and utility associated with young people's experiences of using digital technologies. We try to evidence that even among subjects who have frequent access to digital devices, there are still important gaps and barriers that differentiate their use of these technologies. Data collection was conducted during the first quarter of 2017, using a structural sample based on the following three sociodemographic variables (gender, age and education) and one lifestyle variable related to subjects' technological access. Below we discuss the relevance of the four variables included, although it is important to highlight that it was not possible to consider other relevant variables -such as ethnic origin, geographical habitat or socioeconomic condition-, which are also important in terms of digital stratification. In addition, in table I we present the main characteristics of the respondents.

Table 1. Qualitative sample. Main characteristics of the respondents

\begin{tabular}{|c|c|c|c|c|c|}
\hline ID & City (district)* & Gender & Age Group (birthdate) & $\begin{array}{l}\text { Educational } \\
\text { Level }\end{array}$ & Technological Access \\
\hline $\mathrm{R} 1$ & Rivas & Woman & Pot. Dig. Native (1996) & Secondary & Computer-Oriented \\
\hline $\mathrm{R} 2$ & Rivas & Woman & Pot. Dig. Native (1994) & Secondary & Mobile-Oriented \\
\hline R3 & San Fernando de H. & Man & Pot. Dig. Native (1994) & Secondary & Computer-Oriented \\
\hline $\mathrm{R} 4$ & Rivas & Man & Transition Gen. (1988) & Higher & Mobile-Oriented \\
\hline $\mathrm{R} 5$ & Torrejón de Ardoz & Man & Pot. Dig. Native (1995) & Secondary & Computer-Oriented \\
\hline R6 & Madrid (Centro) & Man & Transition Gen. (1988) & Secondary & Computer-Oriented \\
\hline R7 & Boadilla del Monte & Man & Pot. Dig. Native (1998) & Secondary & Mobile-Oriented \\
\hline $\mathrm{R} 8$ & Madrid (Retiro) & Woman & Dig. Immigrant (1987) & Higher & Computer-Oriented \\
\hline R9 & Madrid (Salamanca) & Man & Transition Gen. (1993) & Higher & Computer-Oriented \\
\hline R10 & Madrid (Tetuán) & Man & Dig. Immigrant (1984) & Higher & Computer-Oriented \\
\hline $\mathrm{R} 11$ & Rivas & Man & Transition Gen. (1992) & Secondary & Mobile-Oriented \\
\hline $\mathrm{R} 12$ & Leganés & Woman & Transition Gen. (1988) & Secondary & Mobile-Oriented \\
\hline R13 & Madrid (Chamartín) & Man & Dig. Immigrant (1986) & Higher & Computer-Oriented \\
\hline
\end{tabular}




\begin{tabular}{llllll}
\hline R14 & Las Rozas & Man & Dig. Immigrant (1985) & Secondary & Computer-Oriented \\
\hline R15 & Madrid (Arganzuela) & Woman & Transition Gen. (1993) & Higher & Computer-Oriented \\
\hline R16 & Madrid (Centro) & Woman & Dig. Immigrant (1982) & Higher & Mobile-Oriented \\
\hline R17 & Madrid (C. Lineal) & Woman & Dig. Immigrant (1987) & Higher & Computer-Oriented \\
\hline R18 & Madrid (Moncloa) & Woman & Transition Gen. (1991) & Higher & Mobile-Oriented \\
\hline R19 & Madrid (Arganzuela) & Woman & Transition Gen. (1990) & Higher & Computer-Oriented \\
\hline R20 & Madrid (Arganzuela) & Woman & Transition Gen. (1990) & Higher & Mobile-Oriented \\
\hline
\end{tabular}

${ }^{\star}$ We include the district in the case of the city of Madrid

Source: Own elaboration

1. Gender. As some authors have pointed out (Antonio \& Tuffley, 2014; Castaño, Martín, \& Martínez, 2011; Hargittai \& Shaw, 2015), gender plays an important role in the delimitation of digital inequalities among young people, especially in terms of the second level of the digital divide. Therefore, at the same level of Internet accessibility, there are important differences among men and women's digital practices related to digital skills, motivations and emotional costs which are mandatory to consider. Our sample is composed by 10 women and 10 men.

2. Age group. Even if there is not a strict limit between the so-called digital natives and digital immigrants (Banaji, 2011; Buckingham, 2011; Kirschner \& De Bruyckere, 2017) it is still important to consider the 'effect' of age in the analysis of the digital inequalities among young people. In our sample, we have considered three age groups: (1) digital immigrants, born between 1982 and 1987 (6 interviews); (2) transition generation, born between 1988 and 1993, who experienced the transition between analogic and digital technologies in the adolescence ( 9 interviews); (3) potential digital natives, born after 1993, so they may have potentially experienced digital technologies from childhood, but not necessarily the material and economic conditions to access to them (5 interviews). This last group roughly coincides with the called post-millennials (DiMock, 2018) or generation Z (Stillman \& Stillman, 2017).

3. Educational level. As many studies have highlighted (Haight et al., 2014; Mariën \& Prodnik, 2014; Robinson, 2009; Van Deursen \& Van Dijk, 2015), educational level 


\section{The Three Levels of the Digital Divide: Barriers in Access,}

Use and Utility of Internet among Young People in Spain

is the most significant variable in defining digital inequalities and digital proficiency among young people, beyond age, gender or ethnic origin. In our sample, we have included students from two different educational backgrounds: 9 respondents have attained secondary compulsory education and 11 respondents have higher education.

4. Technological Access. Finally, the type of technological access is also an important factor to consider in order to analyse digital divide, especially regarding those youngsters who have been socialised through the use of computers and those who mainly access the Internet by means of mobile devices, such as smartphones or tablets (Hjelholt \& Schou, 2018; Thornham \& Gómez Cruz, 2016). In our sample, we have focused on two main groups: (1) mobile-oriented users ( 8 interviews), in which we include people whose majority of digital practices are carried out by the use of smartphones and other mobile devices (tablets); (2) computer-oriented users (12 interviews), in which we include people that use both mobile devices and computers to carry out their digital practices.

\section{RESULTS}

Digital technologies are deeply rooted in young people's experience, and mediates most of their communication, information-seeking, leisure and work activities. However, there are important asymmetries in the specific ways in which technological devices are incorporated to youngsters' daily life. On the one hand, the knowledge of the potentialities and opportunities offered by these platforms and devices are clearly associated with the personal biographical processes of technological socialization, which are developed from childhood but are continuously actualized to new possibilities, tools and personal situations. On the other hand, the process of technological socialization is social by definition, so family members, school mates, teachers, friends and other acquaintances that conform the young people's life worlds also play an important role in their access to digital technologies and in their incorporation to offline practices. Nevertheless, technological socialization is neither straightforward, nor natural or intuitive, but a long-term and continuous process which moves back and forth, and in which people experience several difficulties and barriers, depending on their particular motivation, knowledge and position in the social structure. There-

fore, we have focused in five important gaps or barriers, that are related to the three 
levels of digital divide, and organized in four sections: (1) Access gap, related to the first level of the digital divide, (2) Skills gap, which is one of the most important barriers that inhibit digital inclusion; (3) Emotional and motivation gaps, which we analyse together because of their close interrelation, and which, together with the skills gap, constitute the second level of the digital divide; (4) Utility gap, which is related to the offline returns of digital appropriation, that is, the third level of the digital divide.

\section{Access gap}

Although the access to the Internet is not a main issue for our respondents, there are important asymmetries related to the specific devices used to access and the places in which they use digital technologies. Among almost all respondents, the most common device used to connect to the Internet is the mobile phone, which has become an important part of their lives. Mobile phones are now essential mediators (Lasén \& Casado, 2014) of young people's daily practices, enhance their communication and information-seeking capabilities, and also become an important practical tool for many social and personal activities, including online banking services, taking photos, access to social networks, ordering food, consulting public transport schedules, and so on. In the case of mobile-oriented respondents, smartphones cover most of their daily digital needs, and thus these youngsters do not express the necessity to have a personal computer, which is conceptualized as a more technical and rigid equipment; they express how most of the applications and services they use are better adapted to mobile phones, such as social networks apps, online banking apps, texting services and so on. This mobile-oriented use is more common among respondents without university studies, women and potential digital natives, but not all the subjects follow the same pattern. We have found that, among those people who have not been socialized since childhood in the intensive use of digital technologies, specifically personal computers, it is more common to develop a mobile-oriented use to the Internet, because these respondents can carry out most of their digital practices by means of a smartphone and do not worry about the wide array of possibilities of other technological devices.

"I have two iPads, two smartphones and the television; I have a laptop but we didn't use it yet. (...) I mainly use the iPad and the mobile phone, they seem faster and more comfortable to access to the Internet. (...) The difference is that the mobile phone is always in my pocket and the iPad is at home. Then, if I am, 


\section{The Three Levels of the Digital Divide: Barriers in Access, Use and Utility of Internet among Young People in Spain}

for instance, on the sofa and the iPad is on the table, I use the mobile phone because is closer. But if the iPad is closer and I want to search something or read (I usually search information about the dog) then I use the iPad, because the screen is bigger". (R11. Man, 1992)

"It's because the type of social media services Facebook or Instagram (...) are made to be easily used by mobile phones. If you use them by the web it's boring, you need to be scrolling up and down with the mouse. In the mobile phone you use the app with your fingers, they are much more predictive, and I like that. (...) I only use the computer for working tasks”. (R18. Woman, 1991)

The personal computer, on the other side, is widely associated to professional and educational activities, and some of the respondents highlight that computers are their main working tool. In these cases, computers differentiate from mobile phone because of their higher productivity, the fact that you can use more office software or specific tools related to certain activities, such as audio or video edition, database management, mail services and so one. Even if the computer is seen as a more rigid device than the mobile phone, it also allows people to use a keyboard, a mouse and to have a much bigger screen, thus, in terms of writing and productivity, it is much more effective than mobile devices. Apart from this productive use, some of the respondents also commonly use computer for leisure and personal activities, even if they combine computer accessibility with the use of mobile devices. Computer-oriented respondents, therefore, highlight the wider amount of possibilities granted by computers, such as gaming, for instance, and feel that a computer is, in many cases, more comfortable than mobile devices to access the Internet. This perspective is more common among youngsters with higher education and older people, especially those who have been socialized since childhood in the use of personal computers and can choose which device is better adapted to the particular task they have to do:

"For instance, at the university, I used the computer for all the reports and tasks. For the academic or scientific searches it was much more comfortable. (...) It is for writing, mainly, that I use the computer, and when you have to look for information is faster, you can have several taps opened, and so on". (R8. Woman, 1987)

"For me the computer is always more comfortable, especially at work; I only 
use the mobile phone for Whatsapp and personal issues. (...) It is because the screen is bigger, you have a keyboard, a mouse, etc. Writing a mail with the mobile phone is much harder". (R10. Man, 1984)

\section{Skills gap}

Another important gap in youngsters' engagement with digital technologies is related to the digital skills and capacities needed to use these devices, services and platforms. As we mentioned before, digital skills can be divided between mediumoriented skills, which allow people to physically operate devices and programs, and content-oriented skills, which are related to the specific uses and forms of appropriation of these devices. Among our respondents' discourses, we have not found important difficulties regarding medium-oriented digital skills, both in mobile or fixed devices. Although some respondents (mobile-oriented users) are more familiar with the interfaces of smartphones than with desktop operative systems, such as Windows, Linux or MacOS, they express being able to perform basic tasks with computers, such as turning it on, using a word processor or a browser (Chrome, Mozilla, Explorer, etc.) without special difficulties. However, in most of the cases, respondents found computer use slower and unease, in comparison to the easiness of mobile devices. On the other side, people who frequently use computers at work and people familiarised to computers (computer-oriented users) express quite the opposite. Even if they don't have special difficulties to operate smartphones and mobile devices, they usually suffer from the lack of peripherals (mouse, keyboard, etc.) to operate mobile devices, and feel they use them in a much more clumsy and non-intuitive way than computers. The important issue, though, is the degree of domestication of different technological devices by these two ideal types of users. Thus, mobile-oriented users are more familiar to mobile devices and to operate them with their fingers and tactile screens, whilst computer-oriented users prefer to use accessories such as keyboard and mouse, because this is the way in which they have traditionally learnt to use digital technologies during their technological socialization processes.

"I think that it is easier to type on a computer than on a mobile phone, and also it is better for the eye. I use the tool that is at hand but, if I have to carry out an exhaustive search, I use the computer because I am going to dedicate more time concentrated to do that". (R19. Woman, 1990) 
Similar to Pearce and Rice (2013) findings, we found that computer-oriented respondents have, in general terms, an important informational advantage related to their content-oriented skills. In the case of mobile-oriented users, when they need to use a laptop or a desktop computer for a specific task -bureaucratic procedures, applying for some institutional service, downloading audio-visual media, etc.- they usually ask someone of their inner social circle to help them. They usually do not try to perform the task by themselves because they feel that something could go wrong and they would not be able to fix it. The effect of this support is ambivalent because, on the one hand, it solves the immediate difficulty, and the subject can solve the specific difficulty, but on the other hand it feeds dynamics of self-exclusion and keeps people unmotivated to develop new digital skills that require time, effort and moving beyond their digital comfort zone. In the case of digital immigrants, this lack of content skills regarding computers is more common among women than men, because among this age group it is still more common that men have developed more computer-oriented skills during their socialization. In the case of potential digital natives, this gender divide is not so clear, but among this age group there are, also, many asymmetries in terms of contentoriented digital skills, which show how simplistic metaphors such as digital native are, as this approach cannot describe the variability of young people's digital practices.

"At the beginning I told my father the music I wanted and he used to download it. And then, I told myself, 'I am going to try it', and that was; actually, he explained me a little bit how it worked and that was all." (R1. Woman, 1996).

Finally, it is important to highlight that digital literary processes, among our respondents, are closely related to long-term processes of self-capacitation, in which digital skills are progressively acquired in the daily domestication of digital devices in order to carry out ordinary social practices and tasks. This is why we found an informational skills advantage among those youngsters who had early access to digital devices, especially computers, during childhood and adolescence, and also among those whose educational and labour activities are interwoven with the use of digital technologies.

\section{Emotional and motivation gap}

Two closely interrelated barriers which affect digital practices are related to the emotions and motivations that people experience in their daily use of Internet and 
digital devices. Among our respondents, we have found, specifically, two different sets of emotions which can inhibit and condition young people motivations and interest in using digital technologies. On the one hand, we have found that frequent users of mobile devices tend to feel overwhelmed and exhausted because of the ubiquity and continuous connection granted by this kind of equipment. Even if they express how smartphones are an extremely positive tool in terms of communicating and accessing to information in mobility, they also feel that sometimes they are contextually forced to be always online and to rapidly answer every message or communication that they receive. Although this feeling of anxiety in the use of Internet is widely recognised among all the respondents, it is especially relevant among older ones. In those cases, subjects have experienced in their trajectories previous ways of communication with family, friends or work colleagues, and generally feel that something has been lost with the arrival of digital messaging applications such as WhatsApp or Telegram. They lack the spontaneity and contingency of face-to-face communication or even voice calls, and feel overwhelmed because of the felt necessity of answering back as soon as possible once they receive a text message.

"I think that, in my life, everything is more accelerated, I feel myself more hyperactive, because of the amount of information you have to assimilate for 12 hours, at work, 10 or 11 hours, the amount of impacts you have from WhatsApp, mails, web pages, answering, whatever. (...) I come home and if you take my phone, I even feel anxiety of saying 'everything is quiet'. When I was young I remember it wasn't like that, you could be disconnected, calm, and nothing happened". (R10. Man, 1984)

On the other hand, another set of emotions is related to the use of computers, particularly among mobile-oriented users, who do not always feel they have enough content-related skills to carry out the tasks they need to perform. In these cases, most of the respondents feel frustration and stress, and thus conceptualize computer use as a bad personal experience, which is a powerful inhibitor and barrier that prevents these respondents to engage with computer use again. This kind of emotions is more common among women than men, among people with less educational level and, also, among people who do not use computers frequently in their daily professional and private activities. Our findings, regarding these emotional costs, are very similar to the results described by Huang, Robinson and Cotton (2015), who point out that the frustration 


\section{The Three Levels of the Digital Divide: Barriers in Access, Use and Utility of Internet among Young People in Spain}

and anxiety in digital technology appropriation of most vulnerable groups can feed up processes of self-exclusion of digital technologies, preventing these youngsters to take advantage of the potentialities and opportunities associated to them. In our case, the gap is clear between those subjects who feel comfortable in the use of computers, who can spend time investigating different features of these devices, and those who feel stressed when they have to carry out a task that they do not exactly know, from the start, how can be performed. The first type of digital users can make mistakes and have difficulties in their use of devices, but they feel confident and they will enhance their digital skills in the process of digital appropriation. This group will become much more motivated regarding digital technologies, being able to compensate difficulties in carrying out challenging digital tasks with a strong feeling of self-confidence and a deep attraction and motivation towards these kinds of devices.

"I have many experience with computers, machines, and electronic in general, everything. How to connect it, formatting a computer, etc., for me it's natural because I have grown up surrounded by machines. Most tasks are like going shopping. Then people called for help, and you can teach basic programming tasks. (...) It's like a hobby". (R14. Man, 1985)

On the other hand, the second type of users, more similar to the task-oriented users described by Robinson (2009), feel stressed and frustrated when they confront a difficulty using digital devices, so they tend to self-exclude themselves from the digital sphere and become unmotivated to try new digital tasks, apart from those deeply integrated in their daily activity.

"For me computers are a world impossible to understand. For instance, an Excel sheet, I don't know how to use it. Well, maybe I could use it, but there are too many tabs, too many options, too many things, and I don't use it". (R12. Woman, 1988)

\section{Utility gap}

This last barrier is related to the third level of the digital divide (Ragnedda, 2017), that is, to the offline benefits and outcomes people obtain from the use of digital technologies. In our interviews, there are two predominant contexts in which we can easily describe the centrality of digital technologies in young people life trajectories and 
in their engagement with the social field: information-seeking and communication. Other contexts, such as leisure activities, are also relevant, but information access and communication are the two central points of contemporary people's lives in which digital technologies are utterly integrated.

Regarding information, all of the respondents highlight the importance of Internet and digital technologies for people's access to knowledge and information, both in abstract terms but also in their specific life experiences. Firstly, most of the subjects got their job through the mediation of digital technologies; in some cases, they have used specific platforms oriented to searching available jobs. But in other cases it is just the mediation of social contacts or information-distribution groups that are used to get relevant information associated to working, training or internship opportunities. Secondly, the fact of having the required skills to access to digital information also plays and important role in most of the social practices and daily experiences, and thus the fact of being able to properly use digital technologies is increasingly becoming an important need for activities like shopping, dealing with bureaucratic administration and institutions, organizing trips, using GPS systems and public transports applications to move around, and, in general, using the wide array of services offered by the digital contemporary society. As many authors have stated (Antonio \& Tuffley, 2014; Dalvit, 2018; Selwyn, 2004), digital technologies are increasingly and progressively mediating production processes, but also subjects' personal experiences. This is why Internet access is conceptualized by respondents as an essential informationseeking tool, closely interwoven with their daily practices, and sometimes they express that they would not know how to interact with their life worlds without the mediation of this continuous connectivity.

"On the one hand, Internet makes things simpler but, on the other hand, you are not interested anymore in social relationships, in making a phone call or in meeting in a specific place and knowing that you have to be there at a certain time. So, I think it has made things so simple that we are becoming dumb". (R17. Woman, 1987)

A second context in which Internet have become especially relevant is related to communication and social interaction. In this case, the process of digitalization, and especially the fast generalization of communication mobile devices, has radically changed the ways in which people interact with each other. Among our respond- 


\section{The Three Levels of the Digital Divide: Barriers in Access, Use and Utility of Internet among Young People in Spain}

ents, several communication tools are mentioned, that are associated with different moments of their past life. This allows us to reconstruct the specific change of digital technologies by describing young people's biographic trajectories. Particularly in the case of older respondents, they have experienced, firstly, that the transition from landline phones to cellular phones, during the early 2000s, changed the pattern of communication with friends and family, when calls became independent from spatial and geographical constraints. Secondly, they also experienced the transition between voice calls and SMSs to the wide variety of forms of communication granted by smartphones, in which text, voice, image and audio are combined, engendering a new form of interaction which is not only independent from space but also from temporal constraints, as long as people can just send a message and wait for the later answer. The synchrony of phone calls is no longer an issue and communication becomes enriched, but at the cost of generating a certain dependency from the particular apps, services and devices which allow these new means of communication. As a matter of fact, some respondents declare that they had their first smartphone in order to keep communication with their group of friends, since at the moment when interpersonal communication moved from phone calls to WhatsApp groups, the access to this app became essential in order to prevent digital exclusion.

"I remember that I started to use WhatsApp because I was in a service in which everybody interacted by WhatsApp, and I was completely out". (R16. Woman, 1982)

"I have noted that since I have WhatsApp my social life has grown up exponentially. At the end, people who didn't use to call you, who didn't send you a message, now can text you on a WhatsApp group: 'hey, what's app with you?' At the end is like generating an extreme sociability, even superficial at some point". (R20. Woman, 1990)

\section{DISCUSSION}

In this paper we have analysed the three levels of the digital divide (access, use and utility) that condition subjects' engagement with digital technologies. Through the reconstruction of youngsters' narratives of technological domestication (Silverstone, 
Hirscj, \& Morley, 1992) of Internet in their life trajectories, we can contest, on the first place, most of the cyber-utopian and homogenizing approaches, such as the digital natives metaphor (Prensky, 2001) or concepts like Net generation (Tapscott, 1998) or millennials (Howe \& Strauss, 2000). We agree with Buckingham that there is not just one but various digital generations (2006), which have intensively incorporated digital technologies to their daily life in many different forms, related to their own personal interests, motivations, knowledge, that are conditioned by their specific positioning in the social structure. As Ragnedda (2017) has pointed out, digital divide needs to be seen as a multidimensional social issue rather than a technological one. Our respondents show how even if basic access, analysed in binary terms, is not a problem among them, there are many relevant barriers related to conditions of access (first digital divide), digital skills, motivations and emotions involved in their engagement with the digital world (second digital divide) and, finally, offline outcomes and utility of Internet (third digital divide) are still important gaps that inhibit people to take advantage of all the possibilities associated to the network society.

Regarding access, we have shown the relevance of access quality (Robinson, 2009) and types of devices (Van Deursen \& Van Dijk, 2015) used to connect to the Internet. Among out respondents, the classification between mobile-oriented users and computer-oriented users, which is connected with divergent processes of technological socialization since childhood, is useful to understand the informational advantage experienced by people who can use properly different kinds of devices to perform specific tasks (Pearce \& Rice, 2013) and incorporate to their life the comparative advantages of all of them in different contexts (ubiquity of mobile devices versus productivity of fixed devices). In terms of skills, we found that medium-oriented skills are more or less generalized among our respondents, who generally express being familiar with the use of digital devices. Nevertheless, there are some relevant gender, educational and age differences associated to content-related skills. We found an important gender digital divide among older respondents, a group in which computer skills are much more commonly expressed among men than among women. Also, we discovered the importance of long-term digital literacy processes, which are associated with people's working status and educational level-because labour market and educative systems are two of the principal institutions that enhance subjects' digital literacy-, but also with personal biographic processes of self-capacitation.

Therefore, we introduce the importance of motivation and emotions experience in people's engagement with technology as both facilitators and barriers of digital 
performance. Taking into account the emotional cost theory (Huang et al., 2015) we found how self-esteem and confidence in using digital technologies are key aspects of favouring this process of self-capacitation, whilst frustration, anxiety and lack of confidence can lead to a vicious process of self-exclusion from the digital sphere that enhances digital inequalities (Reisdorf \& Groselj, 2017). Finally, we recognised the importance of the outcomes and benefits people ordinarily obtain by using digital technologies. Among our respondents we focused on two dimensions of social life which are extremely interwoven with digital technologies: information-seeking practices and communication. In both cases we observed how technology plays a central role as a mediation tool (Lasén \& Casado, 2014) of people's practices, but that it is also conceptualized in ambivalent terms: on the one hand, new devices, platforms and services enhance people's opportunities by granting access to a huge amount of information sources, simplifying bureaucratic practices and enabling new forms of communication which can overcome temporal and spatial constraints. On the other hand, though, digital technologies create a strong social dependency, and thus the exclusion from the digital sphere (in terms of access, lack of skills or motivation) is increasingly becoming a new form of social exclusion, that needs to be taken into account. At this point, we agree with Ragnedda when he states that "inequalities born with the introduction of new ICTs will add to those already existing, in a circular and cumulative process" (2017, p. 21).

\section{REFERENCES}

Antonio, A., \& Tuffley, D. (2014). The Gender Digital Divide in Developing Countries. Future Internet, 6(4), 673-687. doi:10.3390/fi6040673

Bakardjieva, M. (2005). Internet Society. The Internet in everyday life. Lonfon: Sage Publications.

Banaji, S. (2011). Disempowering by Assumption: "Digital Natives" and the EU Civic Web Project. In M. Thomas (Ed.), Deconstructing Digital Natives: Young People, Technology, and the New Literacies (pp. 49-66). New York: Routledge. 
Beauchamps, M. (2012). Espace urbain et stratification sociale. Une lecture spatiale des inégalités sociales à l'heure d'Internet. RESET - Recherches En Sciences Sociales Sur Internet, 1, 1-17.

Buckingham, D. (2002). Crecer en la era de los medios electrónicos. Tras la muerte de la infancia. Madrid: Ediciones Morata.

Buckingham, D. (2006). Is there a Digital Generation? In D. Buckingham \& R. Willet (Eds.), Digital Generations. Children, Young People, and New Media (pp. 1-19). Mahwah NJ: Lawrence Erlbaum Associates.

Buckingham, D. (2011). Foreword. In M. Thomas (Ed.), Deconstructing Digital Natives: Young People, Technology, and the New Literacies (pp. ix-xi). New York: Routledge.

Castaño, C. (2008). La segunda brecha digital. Madrid: Cátedra.

Castaño, C., Martín, J., \& Martínez, J. L. (2011). La brecha digital de género en España y Europa: medición con indicadores compuestos. Revista Española de Investigaciones Sociológicas, 136, 127-140. doi:10.5477/cis/reis.136.127

Castells, M. (2011). La era de la información volumen 1: La sociedad red. Madrid: Alianza Editorial.

Compaine, B. (2001). The Digital Divide. Facing a Crisis or Creating a Myth? Boston: MIT.

Correa, T. (2016). Digital skills and social media use: how Internet skills are related to different types of Facebook use among 'digital natives.' Information, Communication \& Society, 19(8), 1095-1107. doi:10.1080/1369118X.2015.1084023

Croon Fors, A. (2013). The Ontology of the Subject in Digitalization. In Handbook of Research on Technoself: Identity in a Technological Society. Hershey, PA: IGI Global.

Dalvit, L. (2018). The language metaphor. An epistemological approach to the digital divide. In M. Ragnedda \& G. W. Muschert (Eds.), Theorizing Digital Divides (pp. 75-87). London: Routledge. 
The Three Levels of the Digital Divide: Barriers in Access,

Use and Utility of Internet among Young People in Spain

DiMaggio, P., \& Hargittai, E. (2001). From the "Digital Divide" to "Digital Inequality": Studying Internet use as Penetration Increases. Working Paper Series 15. doi: $10.1002 /$ bem.20484

DiMock, M. (2018). Defining generations: Where Millennials end and post-Millennials begin. Retrieved April 28, 2018, from http://pewrsr.ch/2GRbL5N

Dutton, W. H., \& Blank, G. (2015). Cultural Stratification on the Internet: Five Clusters of Values and Beliefs among Users in Britain. In L. Robinson, S. R. Cotten, J. Schulz, T. M. Hale, \& A. Williams (Eds.), Communication and Information Technologies Annual. Digital Distinctions and Inequalities (Vol. 10) (pp. 3-28). Bingley: Emerald Group.

Dutton, W. H., \& Reisdorf, B. C. (2017). Cultural divides and digital inequalities: attitudes shaping Internet and social media divides. Information Communication and Society, 1-21. doi:10.1080/1369118X.2017.1353640

Espín, M. (2011). Ciencia, técnica, ideología, globalidad e igualdad. Revista de Estudios de Juventud, 92, 133-150.

Feather, J. (2013). The Information Society: A Study of Continuity and Change. London: Facet Publishing.

Ghobadi, S., \& Ghobadi, Z. (2015). How access gaps interact and shape digital divide: A cognitive investigation. Behaviour \& Information Technology, 34(4), 330-340. doi: 10.1080/0144929X.2013.833650

Gilleard, C. (2018). The place of age in the digital revolution. In S. Taipale, T.-A. Wilska, \& C. Gilleard (Eds.), Digital Technologies and Generational Identity: ICT Usage Across the Life Course (pp. 11-22). Oxon: Routledge.

Gire, F., \& Granjon, F. (2012). Les pratiques des écrans des jeunes français. Déterminants sociaux et pratiques culturelles associées. RESET - Recherches En Sciences Sociales Sur Internet, 1(2012), 1-21. Retrieved from http://www.journal-reset. org/index.php/RESET/article/view/4

Gonzales, A. (2016). The contemporary US digital divide: from initial access to technology maintenance. Information, Communication \& Society, 19(2), 234-248. doi: $10.1080 / 1369118 X .2015 .1050438$ 
Haddon, L. (2007). Roger Silverstone's legacies: Domestication. New Media and Society, 9(1), 25-32. doi:10.1177/1461444807075201

Haight, M., Quan-Haase, A., \& Corbett, B. a. (2014). Revisiting the digital divide in Canada: The impact of demographic factors on access to the Internet, level of online activity, and social networking site usage. Information, Communication \& Society, 17(4), 503-519. doi:10.1080/1369118X.2014.891633

Hargittai, E., \& Shaw, A. (2015). Mind the skills gap: the role of Internet know-how and gender in differentiated contributions to Wikipedia. Information, Communication \& Society, 18(4), 424-442. doi:10.1080/1369118X.2014.957711

Hjelholt, M., \& Schou, J. (2018). The digital divide and classifications. The inscription of citizens into the state. In M. Ragnedda \& G. W. Muschert (Eds.), Theorizing Digital Divides (pp. 173-185). London: Routledge.

Howe, N., \& Strauss, W. (2000). Millennials Rising: The Next Great Generation. Knopf Doubleday Publishing Group.

Huang, K.-T., Robinson, L., \& Cotten, S. R. (2015). Mind the Emotional Gap: The Impact of Emotional Costs on Students Learning Outcomes. In L. Robinson, S. R. Cotten, J. Schulz, T. M. Hale, \& A. Williams (Eds.), Communication and Information Technologies Annual. Digital Distinctions and Inequalities (Vol. 10) (pp. 121-144). Bingley: Emerald Group.

Jones, C. (2011). Students, the Net Generation, and Digital Natives: Accounting for Educational Changes. In M. Thomas (Ed.), Deconstructing Digital Natives: Young People, Technology, and the New Literacies (pp. 30-45). New York: Routledge.

Jones, C., \& Shao, B. (2011). The Net Generation and Digital Natives Implications for Higher Education. York. Retrieved from http://oro.open.ac.uk/30014/

Kirschner, P. A., \& De Bruyckere, P. (2017). The myths of the digital native and the multitasker. Teaching and Teacher Education, 67, 135-142. doi:10.1016/j. tate.2017.06.001

Klinkisch, E., \& Suphan, A. (2018). A "recognitional perspective" on the twenty-first century's digital divide. In M. Ragnedda \& G. W. Muschert (Eds.), Theorizing Digital Divides (pp. 117-130). London: Routledge. 
The Three Levels of the Digital Divide: Barriers in Access,

Use and Utility of Internet among Young People in Spain

Kretchmer, S. B. (2018). Theorizing digital divides through the lens of the social construction of technology and social shaping of technology. In M. Ragnedda \& G. W. Muschert (Eds.), Theorizing Digital Divides (pp. 88-102). London: Routledge.

Lasén, A., \& Casado, E. (Eds.). (2014). Mediaciones tecnológicas. Cuerpos, afectos y subjetividades. Madrid: Centro de Investigaciones Sociológicas.

Livingstone, S. (2008). Internet literacy: Young People's Negotiation of New Online Opportunities. In T. McPherson (Ed.), Digital youth, Innovation and the Unexpected (pp. 101-122). Cambridge MA: the MIT Press. doi:10.1162/ dmal.9780262633598.101

Mariën, I., \& Prodnik, J. a. (2014). Digital inclusion and user (dis)empowerment: A critical perspective. Info, 16(6), 35-47. doi:10.1108/info-07-2014-0030

Montgomery, K. C. (2009). Generation Digital. Politics, Commerce, and Childhood in the Age of the Internet. Cambridge MA: MIT.

Moyo, L. (2018). Rethinking the information society. A decolonial and border gnosis of the digital divide in Africa and the Global South. In M. Ragnedda \& G. W. Muschert (Eds.), Theorizing Digital Divides (pp. 133-145). London: Routledge.

Muschert, G. W., \& Gunderson, R. (2018). The sociology of Simmel and digital divides. Information, value, exchange, and sociation in the networked environment. In M. Ragnedda \& G. W. Muschert (Eds.), Theorizing Digital Divides (pp. 11-20). London: Routledge.

Norris, P. (2000). Information Poverty and the Wired World. The International Journal of Press/Politics, 5(3), 1-6. doi:10.1177/1081180X00005003001

Pearce, K. E., \& Rice, R. E. (2013). Digital Divides From Access to Activities: Comparing Mobile and Personal Computer Internet Users. Journal of Communication, 63(4), 721-744. doi:10.1111/jcom.12045

Prensky, M. (2001). Digital Natives, Digital Immigrants. From On the Horizon, 9(5), $1-6$.

Prensky, M. (2011). Digital Wisdom and Homo Sapiens Digital. In M. Thomas (Ed.), Deconstructing Digital Natives: Young People, Technology, and the New Literacies (pp. 15-29). New York: Routledge. 
Ragnedda, M. (2017). The Third Digital Divide: A Weberian Approach to Digital Inequalities. New York: Routledge.

Ragnedda, M., \& Muschert, G. W. (2018a). Introduction. In M. Ragnedda \& G. W. Muschert (Eds.), Theorizing Digital Divides (pp. 1-7). London: Routledge.

Ragnedda, M., \& Muschert, G. W. (Eds.). (2018b). Theorizing Digital Divides. London: Routledge.

Ragnedda, M., \& Ruiu, M. L. (2018). Social capital and the three levels of digital divide. In M. Ragnedda \& G. W. Muschert (Eds.), Theorizing Digital Divides (pp. 21-34). London: Routledge.

Reisdorf, B. C., \& Groselj, D. (2017). Internet (non-)use types and motivational access: Implications for digital inequalities research. New Media and Society, 19(8), 1157-1176. doi:10.1177/1461444815621539

Rifkin, J. (2011). La tercera revolución industrial. Madrid: Paidós.

Robinson, L. (2009). A Taste for the Necessary. Information, Communication \& Society, 12(4), 488-507. doi:10.1080/13691180902857678

Robinson, L. (2012). Information-Seeking 2.0. The Effects of Informational Advantage. RESET - Recherches En Sciences Sociales Sur Internet, 1, 1-16.

Robinson, L. (2013). Freeways, detours, and dead ends: Search journeys among disadvantaged youth. New Media \& Society, 16(2), 234-251. doi: $\underline{10.1177 / 1461444813481197}$

Robinson, L. (2014). Endowed, entrepreneurial, and empowered-strivers: Doing a lot with a lot, doing a lot with a little. Information, Communication and Society, 17(5), 521-536. doi:10.1080/1369118X.2013.770049

Selwyn, N. (2004). Reconsidering Political and Popular Understandings of the Digital Divide. New Media \& Society, 6(3), 341-362. doi:10.1177/1461444804042519

Selwyn, N. (2009). The digital native: myth and reality. Aslib Proceedings, 61(4), 364379. doi:10.1108/00012530910973776

Silverstone, R., Hirscj, E., \& Morley, D. (1992). Information and communication technologies and the moral economy of the household. In E. Hirsch \& R. Sil- 
The Three Levels of the Digital Divide: Barriers in Access,

Use and Utility of Internet among Young People in Spain

verstone (Eds.), Consuming Technologies: Media and Information in Domestic Spaces (pp. 15-29). London: Routledge.

Sparks, C. (2013). What is the "Digital Divide" and why is it Important? Javnost - The Public, 20(2), 27-46. doi:10.1080/13183222.2013.11009113

Stillman, Da., \& Stillman, J. (2017). Gen Z Work: How the Next Generation Is Transforming the Workplace. HarperCollins.

Straubhaar, J., Tufekci, Z., Spence, J., \& Rojas, V. (2012). Digital inequity in the austin technopolis. An introduction. In J. Straubhaar, J. Spence, Z. Tufekci, \& R. G. Lentz (Eds.), Inequality in the Technopolis: Race, Class, Gender, and the Digital Divide in Austin (pp. 1-32). Austin: University of Texas.

Tapscott, D. (1998). Growing Up Digital. The Rise of the Net Generation. New York: McGraw-Hill.

Tapscott, D. (2008). Grown Up Digital: How the Net Generation is Changing Your World. McGraw-Hill.

Thornham, H., \& Gómez Cruz, E. (2016). [Im]mobility in the age of [im]mobile phones: Young NEETs and digital practices. New Media \& Society, 16(11), 17941809. doi: $10.1177 / 1461444816643430$

Van Aerschot, L., \& Rodousakis, N. (2008). The link between socio-economic background and Internet use: barriers faced by low socio-economic status groups and possible solutions. Innovation: The European Journal of Social Science Research, 21(4), 317-351. doi:10.1080/13511610802576927

Van Deursen, A., \& Van Dijk, J. (2013). The digital divide shifts to differences in usage. New Media \& Society, 16(3), 507-526. doi:10.1177/1461444813487959

Van Deursen, A., \& Van Dijk, J. (2014). Digital Skills. Unlocking the Information Society. Palgrave Macmillan. doi:10.1057/9781137437037

Van Deursen, A., \& Van Dijk, J. (2015). Toward a Multifaceted Model of Internet Access for Understanding Digital Divides: An Empirical Investigation. The Information Society, 31(5), 379-391. doi:10.1080/01972243.2015.1069770 
Weymann, A., \& Sackmann, R. (1994). Modernization and the Generational Structure. Technological Innovation and Technology-Generations in East and West Germany. In H. A. Becker \& P. L. J. Henkers (Eds.), Solidarity of Generations. Demographic, Economic and Social Change and its Consequences (pp. 721-743). Amsterdam: Thesis Publishers.

White, D. S., \& Le Cornu, A. (2011). Visitors and residents: A new typology for online engagement. First Monday, 16(9), 1-15.

Zimic, S., \& Dalin, R. (2011). Actual and Perceived Online Participation Among Young People in Sweden. In M. Thomas (Ed.), Deconstructing Digital Natives: Young People, Technology, and the New Literacies (pp. 137-150). New York: Routledge. 